\title{
PENGARUH KONSENTRASI STRUKTUR PASAR TERHADAP KINERJA INDUSTRI KOMERSIAL PERBANKAN DI INDONESIA PERIODE TAHUN 2007 - 2011
}

\author{
Rofanov \\ Program Studi Ilmu Ekonomi, Universitas Negeri Medan \\ Telp : +628163182424, \\ email: rofanov@gmail.com
}

\begin{abstract}
Based on the ratio of market share of 11 commercial banks discovered the phenomenon gap of the period 2007-2011 where 11 commercial banks dominate the banking market predominantly in Indonesia, including four state-owned banks. This phenomenon has resulted in the banking market structure tends to form an oligopoly, it is obviously affecting the behavior of banks that have a dominant position to maintain supernormal profit, which is reluctant to extend credit with low interest tribes and not a reflection of efficient behavior that ultimately lead to the real sector can not run role in the economy because of factors hampered financing. And with the market conditions are 11 commercial banks were so dominant, which is feared if one bank's collapse could affect the performance of banks in a systemic and even disrupt the Indonesian economy in general. The objectives of this research to determine the form of the banking market structure and analize the influence of concentration market structure and Capital Adequacy Ratio (CAR), Non Performing Loan (NPL), Net Interest Margin (NIM), and Loan to Deposit Ratio (LDR) to Return on Asset (ROA) wich is as a proxy of Financial Performance Banking in 2007 until 2011 periods. The data in this study was collected from Indonesian Banking Directory of 2007-2011. The collected sample was 11 biggest commercial banks over the period from 2007-2011. The analysis model was used to determine the shape of banking market structure by using CR4 concentration ratio (Four Concentration Ratio) on a share of the assets, the share of third-party funding (DPK) and the share of loans, that produce banking that shaped the oligopoly market structure moderate low or concentration oligopoly level IV, where four largest banks a dominate about $42 \%$ - 50\% market share. The estimation of the Fixed Effect Model unknown that concentration market, market share, Capital Adequacy Ratio (CAR), Net Interest Margin (NIM) and the Loan to Deposit Ratio (LDR) has a positive effect on profitability (Return on Assets) as a
\end{abstract}

QE Journal | Vol.02 - No.04 - 43 
proxy for the performance of the banking industry. And for the Non Performing Loan (NPL) has a negatively effect on profitability (Return on Assets) as a proxy for the performance of the banking industry.

Keywords: Market Structure, Financial Performance, CAR, Net Interest Margin, $L D R$.

\section{PENDAHULUAN}

istem perekonomian suatu negara erat kaitannya dengan
keberadaan sektor perbankan. Industri Perbankan memegang
peranan penting bagi pembangunan ekonomi sebagai Financial Intermediary atau perantara pihak yang kelebihan dana dengan pihak yang membutuhkan dana. Menurut Ali (2004), bank didefinisikan sebagai lembaga keuangan yang memiliki izin usaha untuk beroperasi sebagai bank, yaitu menerima penempatan dana-dana yang dipercayakan masyarakat kepada bank tersebut, memberikan pinjaman kepada masyarakat dan dunia usaha pada umumnya, memberi akseptasi atas berbagai bentuk surat utang yang disampaikan pada bank tersebut serta menerbitkan cek. Laporan keuangan suatu bank menunjukkan kondisi keuangan bank secara keseluruhan termasuk kelemahan dan kekuatan yang dimiliki serta kinerja manajemen bank (Kasmir, 2005).

Perkembangan teknologi dan globalisasi telah membawa perubahan mendasar dalam bisnis perbankan. Produk yang ditawarkan oleh industri perbankan juga ditawarkan oleh industri keuangan lainnya. Kondisi ini menyebabkan tingginya persaingan yang dihadapi industri perbankan. Penilaian tingkat kesehatan bank adalah salah satu cara untuk mengukur tingkat kinerja perbankan. Berdasarkan Peraturan Bank Indonesia Nomor 6/10/PBI/2004 tgl 12 April 2004 tentang Sistem Penilaian Tingkat Kesehatan Bank Umum, tingkat kesehatan bank adalah hasil penilaian kualitatif atas berbagai aspek yang berpengaruh terhadap kondisi atau kinerja suatu bank melalui penilaian kuantitatif dan atau penilaian kualitatif terhadap faktorfaktor permodalan, kualitas aset, manajemen, rentabilitas, likuiditas, dan sensitivitas terhadap risiko pasar. Analisis profitabilitas dapat digunakan untuk mengukur kinerja suatu perusahaan yang notabene profit motif 
(Mawardi, 2005). Kinerja (performance) perusahaan dapat dilihat melalui berbagai macam variabel atau indikator.

Perkembangan perbankan setelah tahun 2007 menunjukkan kinerja yang membaik. Hal ini ditunjukkan dalam Tabel 1.2 dengan indikator utama perbankan yang terus menunjukkan tanda-tanda membaik, seperti LDR, NPL, profitabilitas dan CAR. LDR perbankan meningkat sampai $78.77 \%$ diakhir tahun 2011, sementara NPL menurun diangka 2.17\% diakhir tahun 2011. Untuk ukuran profitabilitas, perkembangan kinerja ditunjukkan oleh Net Interest Margin (NIM) dan Return on Assets (ROA) yang cenderung meningkat.

Menurut Husnan (1998) ROA merupakan rasio antara laba sebelum pajak terhadap total asset. Keuntungan (laba) yang diperoleh tersebut digunakan untuk mengukur efektifitas perusahaan dalam memanfaatkan aktiva yang dimiliki. ROA yang menurun menunjukkan efektifitas perusahaan dalam memanfaatkan aktiva yang dimiliki untuk menghasilkan keuntungan (laba) menurun, begitu pula sebaliknya. Semakin besar ROA maka semakin besar profitabilitas perusahaan yang berarti kinerja perusahaan semakin baik. Menurut SE Bank Indonesia Nomor 6/23/DPNP tanggal 31 Mei 2004 ketentuan rasio ROA berkisar antara $0.5 \%-1.25 \%$.

Salah satu ukuran industri perbankan yang sehat adalah kinerja yang baik secara terus menerus. Kinerja bank tersebut dipengaruhi oleh banyak faktor pendukung, salah satunya adalah struktur perbankan itu sendiri dalam satu wilayah. Efisiensi dalam industri perbankan merupakan sarana penting efektivitas menunjang kebijakan moneter mengingat industri perbankan di Indonesia sebagai transmisi kebijakan moneter kepada sektor riil dan hal ini dapat dilihat dalam kinerja rasio keuangan 11 bank umum hasil penelitian periode tahun 2007-2011.

Capital Adequacy Ratio (CAR) menurut Dendawijaya (2005) adalah rasio yang memperlihatkan seberapa jauh seluruh aktiva bank yang mengandung risiko (kredit, penyertaan, surat berharga, tagihan pada bank lain) ikut dibiayai dari dana modal sendiri bank disamping memperoleh dana-dana dari sumber-sumber di luar bank, seperti dana dari masyarakat, pinjaman and lain-lain. Menurut SE Bank Indonesia Nomor 6/23/DPNP tanggal 31 Mei 2004 ketentuan rasio CAR minimal 8 persen. Rasio yang digunakan dalam menghitung risiko kredit adalah Non Performing Loan 
(NPL) yang merupakan kredit yang masuk ke dalam kategori kredit Kurang Lancar, Diragukan dan Macet berdasarkan kriteria yang sudah ditetapkan oleh Bank Indonesia. Bank Indonesia mewajibkan bank-bank agar rasio NPL tidak lebih dari 5\%. Menurut Mawardi (2005) salah satu proksi dari risiko pasar adalah suku bunga, yang diukur dari selisih antara suku bunga pendanaan (funding) dengan suku bunga pinjaman yang diberikan (lending) atau dalam bentuk absolut adalah selisih antara total biaya bunga pendanaan dengan total biaya bunga pinjaman dimana dalam istilah perbankan disebut Net Interest Margin (NIM). Menurut SE Bank Indonesia Nomor 6/23/DPNP tanggal 31 Mei 2004 ketentuan rasio NIM berkisar antara 1.5\%-2\%. Kemampuan likuiditas bank dapat diproksikan dengan LDR (Loan to Deposit Ratio) yaitu perbandingan antara kredit dengan Dana Pihak Ketiga (DPK). Menurut SE Bank Indonesia Nomor 6/23/DPNP tanggal 31 Mei 2004 ketentuan rasio LDR berkisar antara 85\% $100 \%$.

Menurut Sofyan, (2002) ada beberapa alat ukur yang digunakan untuk mengukur tingkat konsentrasi dalam suatu industri, salah satunya Rasio Konsentrasi (Concentration Ratio, CR). Biasanya jumlah perusahaan (N) yang dihitung proporsi pangsa pasarnya adalah 4, sehingga dikenal sebagai CR4. Rasio konsentrasi berkisar antara nol hingga satu dan biasanya dinyatakan dalam persentase. Nilai konsentrasi yang mendekati angka nol mengindikasikan bahwa sejumlah $(\mathrm{N})$ perusahaan memiliki pangsa pasar yang relatif kecil. Sebaliknya, angka rasio konsentrasi yang mendekati satu mengindikasikan konsentrasi yang relatif tinggi. Berdasarkan nilai CR4 untuk pangsa pasar aset, kredit dan dana pihak ketiga. Bank Mandiri, BNI, dan BRI menguasai lebih dari 34\% total aset, total DPK dan total kredit perbankan sehingga menjadi salah satu faktor yang mendukung transmisi kebijakan tidak berjalan dengan baik, dimana diduga adanya semacam oligopoli dibank-bank milik pemerintah.

\section{METODE PENELITIAN}

Penelitian ini dilakukan untuk mengetahui pengaruh variabel struktur pangsa pasar dan konsentrasi serta variabel kerja perbankan yang diukur dari seperti : LDR (Loan to Deposit Ratio), CAR (Capital Adequacy Ratio), pertumbuhan DPK (Dana Pihak Ketiga), dan NIM (Net Interest Margin), NPL (Non Performing Loan), terhadap kinerja industri perbankan yang diukur 
dari profitabilitas/ROA (Return on Assets). Objek penelitian yang diambil adalah penelitian pada industri perbankan dengan kurun waktu 2007 2011. Dengan menggunakan data sekunder berupa data panel atau disebut data longitudinal yaitu sekelompok data individual meliputi data 11 bank umum terbesar dalam pangsa pasar dana pihak ketiga (DPK). Penggunaan data tersebut sebagai data penelitian karena 11 bank umum terbesar tersebut menguasai pangsa lebih dari 65 persen total pangsa pasar bank umum yang ada, sehingga dianggap sampel tersebut dapat mewakili industri perbankan dengan baik. Data yang digunakan merupakan data indikator kinerja perbankan yang antara lain mengenai total aset, total dana pihak ketiga, dan total kredit yang terdapat dalam neraca, dan rasiorasio keuangan seperti : CAR, LDR, NIM, NPL dari bank-bank umum yang dijadikan objek penelitian.

Untuk melihat struktur pasar industri dan menjawab hipotesa pertama yang menyatakan bahwasanya bentuk struktur pasar industri perbankan di Indonesia periode tahun 2007 - 2011 berbentuk oligopoli maka dapat diketahui dengan cara mengukur tingkat konsentrasi dari industri tersebut. Dalam penelitian ini akan digunakan variabelCR4 yaitu rasio konsentrasi 4 bank terbesar untuk mengukur tingkat konsentrasi pada industri perbankan ini dengan satuan persen. Variabel yang akan dijadikan ukuran konsentrasi adalah variabel aset, kredit dan dana pihak ketiga (DPK), yaitu dengan menjumlahkan masing-masing variabel empat bank umum terbesar dalam industri perbankan dibagi dengan total masing-masing variabel dari keseluruhan bank umum. Model yang digunakan dalam penelitian ini adalah :

$$
\begin{aligned}
\text { CR4Aset } & =\frac{\text { Total Aset } 4 \text { bank terbesar }}{\text { Total Aset Seluruh Bank Umum }} \times 100 \% \\
C R 4 K \text { redit } & =\frac{\text { Total Kredit } 4 \text { bank terbesar }}{\text { Total Kredit Seluruh Bank Umum }} \times 100 \% \\
C R 4 D P K & =\frac{\text { Total DPK } 4 \text { bank terbesar }}{\text { Total DPK Seluruh Bank Umum }} \times 100 \%
\end{aligned}
$$

Untuk menjawab hipotesa selanjutnya tentang pengaruh konsentrasi pasar, pangsa pasar dan variabel kontrol CAR, NPL, NIM, LDR terhadap profitabilitas maka model yang digunakan dalam penelitian ini adalah:

QE Journal | Vol.02 - No.04 - 47 


$$
\text { Л }=\mathrm{f}(C M, M S, V i)+\epsilon i
$$

Dimana :

$\Lambda$ = profit rate, $\mathrm{ROA}$ (return on assets)

$\mathrm{CM}=$ konsentrasi pasar (concentration market) DPK

MS = pangsa pasar (market share) DPK

$\mathrm{V}_{\mathrm{i}}$ = vektor dari variabel kontrol lain yang mempengaruhi profit kinerja perbankan (CAR, NPL, NIM, LDR)

$\epsilon_{\mathrm{i}} \quad=$ error term for bank $\mathrm{i}$

Model diatas dijabarkan dalam persamaan model ekonometrika:

$$
Л=0+1 C M+2 M S+3 C A R+4 N P L+5 N I M+6 L D R+\epsilon i
$$

Dimana :

$\Lambda \quad=$ profit rate, $\mathrm{ROA}$ (return on assets)

$\beta_{0}=$ konstanta

$\beta_{1} \mathrm{CM}=$ koefisien konsentrasi pasar dana pihak ketiga

$\beta_{2} \mathrm{MS}=$ koefisien pangsa pasar dana pihak ketiga

$\beta_{3} \mathrm{CAR}=$ koefisien CAR (Capital Adequacy Ratio)

$\beta_{4}$ NPL $=$ koefisien NPL (Non Performing Loan)

$\beta_{5} \mathrm{NIM}=$ koefisien NIM (Net Interest Margin)

$\beta_{6} \mathrm{LDR}=$ koefisien LDR (Loan to Deposit Ratio)

$\mathrm{E}_{\mathrm{i}} \quad=$ error term for bank $\mathrm{i}$

Rasio Return on Asset (ROA) memberikan informasi seberapa efisien bank dalam melakukan kegiatan usahanya, karena rasio ROA mengindikasikan seberapa besar keuntungan yang dapat diperoleh rata-rata terhadap setiap rupiah asetnya. Sesuai SE No. 6/23/DPNP tanggal 31 Mei 2004 rasio ROA dirumuskan sebagai berikut:

$$
R O A=\frac{\text { Laba Sebelum Pajak }}{\text { Rata }- \text { Rata Total Aset }}
$$

Rasio keuangan yang digunakan dalam mengukur risiko kredit adalah Non Performing Loan (NPL). NPL menunjukkan kemampuan bank dalam mengelola kredit bermasalah, sehingga semakin tinggi rasio NPL maka semakin buruk kualitas kredit bank atau mengindikasikan bahwa tingkat risiko atas pemberian kredit pada bank tersebut cukup tinggi sehingga memberikan dampak negatif terhadap profitabilitas (Mawardi, 2005). Sesuai SE No. 6/23/DPNP tanggal 31 Mei 2004 rasio NPL dirumuskan sebagai berikut:

QE Journal | Vol.02 - No.04 - 48 


$$
N P L=\frac{\text { Total Kredit Bermasalah }}{\text { Rata }- \text { Rata Total Aset }}
$$

Menurut Mawardi (2005) salah satu proksi dari risiko pasar adalah suku bunga, yang diukur dari selisih antara suku bunga pendanaan (funding) dengan suku bunga pinjaman yang diberikan (lending) atau dalam bentuk absolut adalah selisih antara total biaya bunga pendanaan dengan total biaya bunga pinjaman dimana dalam istilah perbankan disebut Net Interest Margin (NIM). Net Interest Margin menunjukkan kemampuan manajemen bank dalam menghasilkan bunga bersih berpengaruh terhadap tingkat pendapatan bank akan total assetnya. Sesuai SE No.6/23/DPNP tanggal 31 Mei 2004 rasio NIM dirumuskan sebagai berikut:

$$
N I M=\frac{\text { Pendapatan Bunga Bersih }}{\text { Rata }- \text { Rata Aktiva Produktif }}
$$

Peraturan Bank Indonesia menyatakan bahwa kemampuan likuiditas bank dapat diproksikan dengan LDR (Loan to Deposit Ratio) yaitu perbandingan antara kredit dengan Dana Pihak Ketiga (DPK). Rasio ini digunakan untuk menilai likuiditas suatu bank yang dengan cara membagi jumlah kredit yang diberikan oleh bank terhadap dana pihak ketiga. Kredit yang diberikan tidak termasuk kredit kepada bank lain sedangkan untuk dana pihak ketiga adalah giro, tabungan, simpanan berjangka, sertifikat deposito. Standar yang digunakan Bank Indonesia untuk rasio LDR adalah 80\% hingga 110\%. Sesuai SE No.6/23/DPNP tanggal 31 Mei 2004 rasio LDR dirumuskan sebagai berikut:

$$
L D R=\frac{\text { Total Kredit }}{\text { Total Dana Pihak Ketiga }}
$$

Penggunaan modal bertujuan untuk mencukupi segala kebutuhan yang menunjang kegiatan operasi bank. Analisis terhadap modal dilakukan untuk mengukur kekayaan bank dan untuk mengetahui apakah modal yang dimiliki bank telah cukup untuk mendukung kegiatan bank dan menyerap kerugian. Penetapan Capital Adequacy Ratio (CAR) sebagai variabel yang mempengaruhi profitabilitas didasarkan hubungannya dengan tingkat risiko bank. Tingginya rasio capital dapat melindungi nasabah, sehingga dapat meningkatkan kepercayaan nasabah terhadap bank dan menunjukkan bahwa semakin besar Capital Adequacy Ratio (CAR) maka Return On Asset (ROA) yang diperoleh bank akan semakin besar dan

QE Journal | Vol.02 - No.04 - 49 
berpengaruh positif karena semakin besar Capital Adequacy Ratio (CAR) maka semakin tinggi kemampuan permodalan bank dalam menjaga kemungkinan timbulnya risiko kerugian kegiatan usahanya sehingga kinerja bank juga meningkat. Sesuai SE No.6/23/DPNP tanggal 31 Mei 2004 rasio CAR dirumuskan sebagai berikut :

$$
C A R=\frac{\text { Modal }}{A T M R}
$$

Uji normalitas bertujuan untuk menguji apakah dalam model regresi variabel terikat dan variabel bebas, keduanya mempunyai distribusi normal atau tidak. Model regresi yang baik adalah distribusi data normal atau mendekati normal. Normalitas dapat dideteksi dengan menggunakan Uji Jarque-Berra (JB) dan metode grafik. Penelitian ini akan menggunakan metode J-B Test yang dilakukan dengan menghitung skweness dan kurtosis, apabila J-B hitung < nilai $\mathrm{X}^{2}$ (Chi Square) tabel, maka nilai residual berdistribusi normal.

$$
J-B \text { hitung }=\frac{s 2}{6}+\left(\frac{k-3}{24}\right)^{2}
$$

Dimana : $\mathrm{S}=$ Skewness statistik $; \mathrm{K}=$ Kurtosis. Jika nilai J-B hitung $>\mathrm{J}-\mathrm{B}$ tabel, maka hipotesis yang menyatakan bahwa residual terdistribusi normal ditolak dan sebaliknya.

Menurut Ghozali (2005) uji multikolinearitas bertujuan menguji apakah pada model regresi ditemukan adanya korelasi antar variabel independen. Pada model regresi yang baik seharusnya antar variabel independen tidak terjadi kolerasi. Untuk mendeteksi ada tidaknya multikoliniearitas dalam model regresi dapat dilihat dari tolerance value atau variance inflation factor

Menurut Ghozali (2005) uji autokorelasi digunakan untuk menguji apakah dalam model regresi linear ada korelasi antara kesalahan pengganggu pada periode $t$ dengan kesalahan pengganggu pada periode $t-1$ (sebelumnya). Regresi yang baik adalah yang bebas dari autokorelasi. Pengujian autokerelasi dilakukan dengan uji Durbin-Watson dengan pengambilan keputusan :

$\mathrm{Ho}=$ tidak ada autokorelasi $(\mathrm{r}=0) ; \mathrm{Ha}=$ ada autokorelasi $(\mathrm{r} \neq 0)$

Ketepatan fungsi regresi sampel dalam menaksir nilai aktual dapat diukur dari goodness of fit nya. Secara statistik, setidaknya ini dapat diukur dari

QE Journal | Vol.02 - No.04 - 50 
nilai statistik $t$, nilai statistik $F$, dan nilai koefisien determinansi $\left(R^{2}\right)$. Perhitungan statistik disebut signifikan secara statistik, apabila uji nilai statistiknya berada dalam daerah kritis (daerah dimana Ho ditolak). Sebaliknya, disebut tidak signifikan bila uji nilai statistiknya berada dalam daerah dimana Ho diterima (Ghozali, 2005).

Menurut Ghozali (2005) uji statistik F menunjukkan apakah semua variabel independen atau bebas yang dimasukkan dalam model mempunyai pengaruh secara bersama-sama terhadap variabel dependen atau terikat. Tingkat signifikan dalam penelitian ini adalah $5 \%$, artinya risiko kesalahan mengambil keputusan adalah 5\%. Nilai $\mathrm{F}$ hitung dapat dicari dengan rumus (Gujarati, 2010):

$$
F_{-} \text {Hitung }=\frac{\left(R^{2} /(k-1)\right)}{\left(1-R^{2}\right) /(N-k)}
$$

Dimana: $\mathrm{R}^{2}=$ Koefisien Determinasi ; $\mathrm{k}=$ Banyaknya koefisien regresi ; $\mathrm{N}=$ Banyaknya Observasi.

Uji $t$ menunjukkan seberapa jauh pengaruh satu variabel independen secara individual dalam menerangkan variasi variabel dependen. Tingkat signifikan dalam penelitian ini adalah 5\%, artinya risiko kesalahan mengambil keputusan adalah $5 \%$. Nilai $t$ hitung dapat dicari dengan rumus (Gujarati, 2010):

$$
t_{\text {hitung }}=\frac{\text { Koefisien Regresi }}{\text { Standar Deviasi }}
$$

Bila - ttabel $<-$-thitung dan thitung $<t_{\text {tabel, }}$, variabel independen secara individu tak berpengaruh terhadap variabel dependen. Bila thitung $>$ tabel dan - thitung $<-$ tabel, variabel independen secara individu berpengaruh terhadap variabel dependen.

Uji koefisien determinasi digunakan untuk mengetahui tingkat ketepatan yang paling baik dalam analisis regresi, hal ini ditunjukkan oleh besarnya koefisien determinasi $\left(\mathrm{R}^{2}\right)$. Nilai koefisien determinasi adalah 0 sampai 1 . Koefisien determinasi dapat dicari dengan rumus (Gujarati, 2010):

$$
R^{2}=\frac{E S S}{T S S}=1-\frac{\sum_{e i} 2}{\sum Y i^{2}}
$$

QE Journal | Vol.02 - No.04 - 51 


\section{HASIL DAN PEMBAHASAN}

Pada akhir periode penelitian, yaitu pada tahun 2011 total pasar aset yang dikuasai oleh 4 bank umum terbesar mencapai 46,61 persen dan dari 11 bank yang diteliti mencapai 67,38 persen yang artinya hanya tersisa 32,62 persen dari luas keseluruhan pasar aset bank umum. Begitu juga dengan total pasar DPK yang dikuasai oleh 4 bank umum terbesar mencapai 50,63 persen dan dari 11 bank yang diteliti mencapai 71,78 persen yang artinya hanya tersisa 28,22 persen dari luas keseluruhan pasar DPK bank umum. Untuk total pasar kredit yang dikuasai oleh 4 bank umum terbesar mencapai 46,03 persen dan dari 11 bank yang diteliti mencapai 71,37 persen yang artinya hanya tersisa 28,63 persen dari luas keseluruhan pasar kredit bank umum. Hal ini menunjukkan bahwa industri perbankan nasional berstruktur persaingan tidak sempurna karena penguasaan pasar yang tidak sama antar perusahaan/bank yang bersaing didalamnya, maka artinya industri perbankan Indonesia berstruktur oligopoli.

Sehingga dari hasil perhitungan rasio konsentrasi CR4 pada Tabel 1, dengan berdasarkan pada kriteria oligopoli menurut Bain (1987), maka struktur pasar industri perbankan Indonesia periode 2007 - 2011 adalah berbentuk oligopoli konsentrasi moderat rendah atau oligopoli tipe IV, dimana pada tipe ini dinyatakan bahwa empat perusahaan terbesar menguasai sekitar 38\%-49\% penawaran output dan bahkan pada pangsa dana pihak ketiga (DPK) berbentuk oligopoli konsentrasi moderat tinggi dengan nilai CR4 sebesar 50,63 persen pada tahun 2011.

Tabel 1. Rasio Konsentrasi CR4 Periode 2007 - 2011

\begin{tabular}{cccc}
\hline Tahun & CR4 Aset (\%) & CR4 DPK (\%) & CR4 Kredit (\%) \\
\hline $\mathbf{2 0 0 7}$ & 46,52 & 49,53 & 42,26 \\
$\mathbf{2 0 0 8}$ & 45,52 & 49,25 & 42,85 \\
$\mathbf{2 0 0 9}$ & 48,20 & 51,14 & 45,12 \\
$\mathbf{2 0 1 0}$ & 47,43 & 49,93 & 44,37 \\
$\mathbf{2 0 1 1}$ & 46,61 & 50,63 & 46,03 \\
\hline
\end{tabular}

Sumber : Statistik Perbankan Indonesia, Bank Indonesia, 2012 (diolah)

Untuk mengetahui pengaruh struktur pasar terhadap kinerja industri perbankan dilakukan regresi berganda dengan menggunakan metode panel data yang menggabungkan antara data cross section yaitu data 11 bank umum terbesar dengan data time series dari tahun 2007 hingga tahun

QE Journal | Vol.02 - No.04 - 52 
2011. Penetapan model yang digunakan, apakah Efek Tetap (Fixed Effect) atau Efek Random (Random Effect) didasarkan pada uji Hausman (Hausman's test of specification model) yang mengikuti distribusi X2 .

Hipotesis yang digunakan adalah: H0 : Estimator random konsisten; H1 : Estimator random tidak konsisten. Apabila H0 diterima, artinya model Efek Random lebih baik digunakan daripada model Efek Tetap, demikian sebaliknya. H0 diterima/ditolak jika X2 hit $<$ X2 tab artinya H0 diterima, dan jika X2 hit > X2 tab artinya H0 ditolak. Nilai X2 hit atau nilai Hausman (H) diperoleh dari perbedaan nilai koefisien dan kovarian antara kedua metode.

$$
H=(b F E-b R E) 1[\operatorname{cov}(b F E)-\operatorname{cov}(b R E)]-1(b F E-b R E)
$$

\section{dimana:}

$\mathrm{bFE}=$ Matriks koefisien estimator dari model Efek Tetap

$\mathrm{bRE}=$ Matriks koefisien estimator dari model Efek Random

$\operatorname{cov}(\mathrm{bFE})=$ Matriks kovarian koefisien estimator dari model Efek Tetap cov $(b R E)=$ Matriks kovarian koefisien estimator dari model Efek Random

Uji Hausman menghasilkan nilai Hausman-hitung 0.02991233 dibandingkan dengan nilai $X^{2}{ }_{90 ; 0,1}$ tabel sebesar 73,2912 maka Ho ditolak atau $\mathrm{H}_{1}$ tidak ditolak. Artinya, model yang tepat digunakan untuk menganalisis data pada penelitian ini adalah model Efek Tetap. Nilai Fhitung sama dengan 40,77594 (lebih besar dari $F_{5,900,1}$ tabel =1,99). Berarti secara bersama-sama (serempak) variabel-variabel bebas (MS, CM, CAR, LDR NIM dan NPL) berpengaruh terhadap variabel terikat (ROA). Hasil estimasi telah memenuhi uji kesesuaian model untuk uji serempak, sehingga hasil estimasi dapat digunakan untuk analisis. $\mathrm{R}^{2}$ terletak antara 0 dan $1 . R^{2}$ sama dengan 1, berarti variabel-variabel bebas menjelaskan 100 persen variasi variabel terikat. Sebaliknya, $R^{2}$ sama dengan 0 , berarti variabel-variabel bebas dalam model tidak menjelaskan sedikitpun variasi variabel terikat. Model dikatakan lebih baik kalau $\mathrm{R}^{2}$ semakin dekat dengan 1 (Gujarati, 2010). Estimasi model menghasilkan $\mathrm{R}^{2}$ sebesar 0,9429. Artinya, keberadaan variabel-variabel bebas (MS, CM, CAR, LDR NIM dan NPL) mampu menjelaskan variabel terikat (ROA) sebesar 94,29 persen, selebihnya yang 15,71 persen dijelaskan oleh variabel-variabel lain diluar model. Dengan $R^{2}$ 0,9429 maka hasil estimasi memenuhi uji kesesuaian dari aspek koefisien determinasi. Hasil estimasi layak dianalisis.

QE Journal | Vol.02 - No.04 - 53 
Uji parsial juga disebut uji tingkat-penting (test of significance). Nilai thitung MS sama dengan 0,556656 dengan nilai probabilitas t sebesar 0,5807 yang berarti variabel MS berpengaruh secara positif namun tidak signifikan terhadap ROA pada tingkat kepercayaan 10 persen, CM sama dengan 1,765130 dengan nilai probabilitas $t$ sebesar 0,0848 yang berarti variabel CM berpengaruh positif dan signifikan terhadap variabel ROA dengan tingkat kepercayaan 10 persen, CAR sama dengan 2,300103 dengan nilai probabilitas $t$ sebesar 0,0265 yang berarti variabel CAR berpengaruh positif dan signifikan terhadap variabel ROA dengan tingkat kepercayaan 10 persen, LDR sama dengan 3,019128 dengan nilai probabilitas t sebesar 0,0043 yang berarti variabel LDR berpengaruh positif dan signifikan terhadap variabel ROA dengan tingkat kepercayaan 5 persen, NIM sama dengan 2,153249 dengan nilai probabilitas t sebesar 0,0371 yang berarti variabel NIM berpengaruh positif dan signifikan terhadap variabel ROA dengan tingkat kepercayaan 5 persen, dan NPL sama dengan -2,504420 dengan nilai probabilitas $t$ sebesar 0,0162 yang berarti variabel NPL berpengaruh negatif dan signifikan terhadap variabel ROA dengan tingkat kepercayaan 5 persen. Jadi, hasil estimasi model telah memenuhi uji kesesuaian dari aspek uji parsial. Hasil estimasi model dapat dianalisis. Dari hasil estimasi dengan menggunakan metode efek tetap, menghasilkan nilai statistik DW sebesar 2,249. Angka ini terletak di sebelah kanan tengah gambar berikut, daerah tersebut menunjukkan daerah tidak dapat disimpulkan (no decision). Dengan nilai DW sebesar 2,249 yang terletak pada daerah yang tidak dapat disimpulkan, sehingga model yang digunakan juga tidak dapat disimpulkan apakah ditolak atau tidak.

Uji multikolinearitas menggunakan VIF dan Tolerence. Untuk menghitung VIF dan Tolerence terlebih dahulu ditentukan matriks korelasi variabel MS, CM, CAR, LDR NIM, dan NPL yang ditunjukkan pada Tabel 2. Nilai VIF yang semakin besar menunjukkan masalah multikolinearitas yang semakin serius. Kaidah yang digunakan adalah jika VIF lebih besar dari 10 dan $R_{j}^{2}$ lebih besar dari 0,90 maka variabel tersebut memiliki kolinearitas yang tinggi. 
Tabel 2. Matriks Korelasi Variabel Bebas

\begin{tabular}{lrrrrrrr}
\hline & ROA & MS & CM & CAR & LDR & NIM & NPL \\
\hline ROA & 1.000000 & & & & & & \\
MS & -0.542781 & 1.000000 & & & & & \\
CM & 0.541181 & -0.576696 & 1.000000 & & & & \\
CAR & -0.457302 & 0.171316 & -0.596766 & 1.000000 & & & \\
LDR & 0.261283 & -0.063530 & -0.288657 & 0.259776 & 1.000000 & & \\
NIM & 0.491429 & -0.294848 & -0.003522 & -0.136711 & -0.324774 & 1.000000 & \\
NPL & -0.441221 & 0.460991 & 0.208342 & 0.188711 & -0.254825 & -0.648882 & 1.000000 \\
\hline
\end{tabular}

Sumber : Hasil Olah Dengan EViews 5,0.

Nilai VIF dari korelasi variabel bebas pada Tabel 3 tidak terdapat variabel yang memiliki nilai VIF yang lebih besar dari 10. Artinya, bahwa seluruh variabel yang diteliti terbebas dari masalah kolinieritas ganda.

Tabel 3. Nilai VIF dari Korelasi Parsial Variabel

\begin{tabular}{cccccccr}
\hline & ROA & MS & CM & CAR & LDR & NIM & NPL \\
\hline ROA & & & & & & & \\
MS & 0.6481801 & & & & & & \\
CM & 2.1795087 & 0.6342377 & & & & & \\
CAR & 0.6861996 & 1.2067326 & 0.6262658 & & & & \\
LDR & 1.3536984 & 0.940265 & 0.7760017 & 1.3509424 & & & \\
NIM & 1.9662938 & 0.7722914 & 0.9964904 & 0.8797311 & 0.7548457 & & \\
NPL & 0.6938561 & 1.8552566 & 1.2631717 & 1.2326064 & 0.7969239 & 0.6064715 & \\
\hline
\end{tabular}

Sumber : Hasil Olah Dengan EViews 5,0.

Hasil uji normalitas dapat dilihat pada nilai Jarque-Bera Test yang menunjukkan bahwa residual ROA nilai JB $=0,353146$ dan Probability = 0,838138; Residual MS nilai JB $=0,311671$ dan Probability $=0,855700$; Residual CM nilai JB = 1,827874 dan Probability =0,400943; Residual CAR nilai JB $=0,576201$ dan Probability $=0,749686$; Residual LDR nilai JB = 0,351279 dan Probability $=0,838920 ;$ Residual NIM nilai JB $=0,232280$ dan Probability = 0,890351; dan residual NPL nilai JB =0,628754 dan Probability = 0,730244 . Seluruh variabel memiliki nilai JB lebih besar pada $\alpha=10$ persen, artinya residual dari profitabilitas (ROA) terdistribusi secara normal atau memenuhi asumsi normalitas. 
Market Share atau pangsa pasar pada penelitian ini dihitung dengan memperhitungkan total dana pihak ketiga yang dimiliki oleh sebuah bank relatif terhadap total dana pihak ketiga bank umum dalam industri perbankan dengan satuan persen. Dari hasil estimasi variabel MS dengan data pangsa pasar Dana Pihak Ketiga berpengaruh positif. Dengan koefisien regresi sebesar 4,562070 menunjukkan bahwa bila terjadi kenaikan MS sebesar 1 persen akan meningkatkan ROA sebesar 4,56. Begitupun sebaliknya, jika MS turun sebesar 1 persen akan menurunkan ROA sebesar 4,56 persen. Hal ini menunjukkan bahwa industri perbankan di Indonesia yang dalam penelitian ini diwakili oleh 11 bank umum terbesar yang menguasai lebih dari 70 persen total pangsa pasar, Dengan demikian akan terjadi hubungan positif antara profitabilitas sebagai proksi kinerja dengan pangsa pasar sebagai proksi dari struktur pasar.

Konsentrasi merupakan proksi dari kekuasaan pasar (market power) dimana konsentrasi pasar yang semakin besar dalam industri tersebut akan mendapatkan laba super normal. Oleh karena itu, konsentrasi pasar akan berpengaruh secara positif dengan profitabilitas sebagai proksi dari kinerja. Dari hasil estimasi konsentrasi pasar (Concentration Market / CM) dengan data dana pihak ketiga dimana hasil berpengaruh positif dan signifikan pada tingkat kepercayaan 90 persen. Dengan koefisien regresi sebesar 0,851701 menunjukkan bahwa bila terjadi kenaikan $\mathrm{CM}$ sebesar 1 persen akan meningkatkan ROA sebesar 0,85. Begitupun sebaliknya, jika CM turun sebesar 1 persen akan menurunkan ROA sebesar 0,85 persen.

Capital Adequacy Ratio (CAR) sebagai variabel kontrol yang berpengaruh positif terhadap profit merupakan rasio kecukupan modal. Rasio ini dihitung dengan membagi modal sendiri dengan aktiva tertimbang menurut rasio ATMR dengan satuan persen. Dari hasil estimasi penelitian ini menunjukkan bahwa pengaruh CAR positif dan signifikan pada tingkat kepercayaan 90 persen. Dengan koefisien regresi sebesar 0,059185 menunjukkan bahwa jika terjadi kenaikan CAR sebesar 1 persen maka akan meningkatkan ROA sebesar 0,06. Begitupun sebaliknya, jika terjadi penurunan CAR sebesar 1 persen akan menurunkan ROA sebesar 0,06.

Kemampuan likuiditas bank dapat diproksikan dengan Loan to Deposit Ratio yaitu perbandingan antara kredit dengan Dana Pihak Ketiga. Semakin tinggi Loan to Deposit Ratio maka laba bank semakin meningkat (dengan asumsi bank tersebut mampu menyalurkan kreditnya dengan

QE Journal | Vol.02 - No.04 - 56 
efektif), dengan meningkatnya laba bank, maka kinerja bank juga meningkat sehingga berpengaruh positif terhadap Return On Asset. Dari hasil estimasi penelitian ini, variabel LDR memiliki nilai $t$ hitung $>t$ tabel yang berarti variabel LDR secara individu signifikan berpengaruh terhadap variabel ROA. Pengaruh LDR terhadap ROA positif dan signifikan pada tingkat kepercayaan 90 persen. Dengan koefisien regresi sebesar 0,030177 menunjukkan bahwa jika terjadi kenaikan LDR sebesar 1 persen akan meningkatkan ROA sebesar 0,03. Sebaliknya jika terjadi penurunan LDR sebesar 1 persen akan menurunkan ROA sebesar 0,03.

Net Interest Margin menunjukkan kemampuan manajemen bank dalam menghasilkan bunga bersih berpengaruh terhadap tingkat pendapatan bank akan total assetnya. Dalam SE No. 6/23/DPNP tanggal 31 Mei 2004 tentang penilaian tingkat kesehatan bank umum adalah dengan menggunakan metode CAMELS yang salah satunya menjelaskan tentang Net Interest Margin yang merupakan rasio yang digunakan untuk mengukur kemampuan manajemen bank dalam mengelola aktiva produktifnya untuk menghasilkan pendapatan bunga bersih. Pendapatan bunga bersih diperoleh dari pendapatan bunga dikurangi beban bunga. Semakin besar rasio ini maka meningkatkan pendapatan bunga atas aktiva produktif yang dikelola bank sehingga kemungkinan suatu bank dalam kondisi bermasalah semakin kecil. Dengan meningkatnya pendapatan bunga maka dapat memberikan kontribusi laba kepada bank. Dari penelitian ini dimana hasil estimasi variabel NIM berpengaruh positif dan signifikan pada tingkat kepercayaan 90 persen. Dengan koefisien sebesar 0.189718 menunjukkan bahwa jika variabel NIM meningkat 1 persen akan meningkatkan ROA sebesar 0,19 persen. Dan bila NIM turun sebesar 1 persen akan meningkatkan ROA sebesar 0,19 persen.

Non Performing Loan / NPL menunjukkan kemampuan bank dalam mengelola kredit bermasalah, sehingga semakin tinggi rasio NPL maka semakin buruk kualitas kredit bank atau mengindikasikan bahwa tingkat risiko atas pemberian kredit pada bank tersebut cukup tinggi. Menurut Peraturan Bank Indonesia Nomor 11/25/PBI/2009 tentang Perubahan Atas Peraturan Bank Indonesia Nomor 5/8/PBI/2003 tentang Penerapan Manajemen Risiko Bagi Bank Umum, adalah risiko akibat kegagalan debitur dan/atau pihak lain dalam memenuhi kewajiban kepada bank. Risiko kredit timbul akibat debitur tidak mampu memenuhi kewajibannya 
kepada bank yang mengakibatkan bank menderita kerugian dimana peningkatan NPL dalam jumlah yang banyak dapat menimbulkan masalah bagi kesehatan bank, oleh karena itu bank dituntut untuk selalu menjaga kredit tidak dalam posisi NPL yang tinggi. Hasil estimasi penelitian ini menunjukkan pengaruh variabel NPL berpengaruh negatif dan signifikan pada tingkat kepercayaan 90 persen, dengan koefisien regresi sebesar 0,205125 menunjukkan bahwa bila NPL naik sebesar 1 persen akan menurunkan ROA sebesar 0,21 persen. Sebaliknya, jika NPL turun sebesar 1 persen akan meningkatkan ROA sebesar 0,21 persen.

\section{SIMPULAN DAN SARAN}

Berdasarkan hasil perhitungan rasio konsentrasi 4 bank terbesar (CR4) pada pangsa aset, pangsa dana pihak ketiga (DPK), dan pangsa kredit, industri perbankan Indonesia selama periode penelitian memiliki CR4 lebih dari 42 persen yang artinya dengan berdasarkan pada kriteria oligopoli menurut Bain (1987:103), maka struktur pasar industri komersial perbankan di Indonesia pada periode tahun 2007 - 2011 adalah berbentuk oligopoli konsentrasi moderat rendah atau oligopoli tipe IV, dimana pada tipe ini dinyatakan empat perusahaan terbesar menguasai sekitar 38\%-49\% penawaran output dan bahkan pada pangsa dana pihak ketiga (DPK) berbentuk oligopoli konsentrasi moderat tinggi dengan nilai CR4 sebesar 50 persen.Dari nilai koefisien determinasi pada hasil estimasi maka variabel profitabilitas kinerja industri perbankan di Indonesia mampu dijelaskan oleh variabel struktural yaitu konsentrasi pasar dan pangsa pasar ; variabel kontrol yaitu rasio kecukupan modal, rasio pinjaman terhadap simpanan, rasio pasar dan rasio kredit mampu dijelaskan dengan model yang digunakan. Variabel-variabel yang digunakan menjelaskan variabel profitabilitas kinerja industri perbankan di Indonesia menunjukkan arah pengaruh yang sesuai dengan hipotesis. Variabel struktur pasar, variabel rasio kecukupan modal, variabel rasio pinjaman terhadap simpanan, dan variabel rasio pasar berpengaruh positif dan signifikan. Sementara variabel konsentrasi pasar berpengaruh positif namun tidak signifikan, sedangkan variabel rasio kredit berpengaruh negatif dan signifikan terhadap profitabilitas.Besarnya nilai koefisien variabel-variabel yang menjelaskan profitabilitas kinerja industri perbankan di Indonesia, yang terbesar adalah variabel pangsa pasar (Market Share) sebesar 4,562070, diikuti berturut-turut oleh variabel 
konsentrasi pasar (Concentration Market) sebesar 0,851701, rasio pasar (Net Interest Margin) sebesar 0,189718, rasio kecukupan modal (Capital Adequacy Ratio) sebesar 0,059185, rasio pinjaman terhadap simpanan (Loan to Deposit Ratio) sebesar 0,030177 dan rasio kredit (Non Performing Loan) sebesar 0,205125.

Dalam hal ini disarankan agar peran pemerintah sebagai regulator diharapkan lebih ditingkatkan dalam mengawasi dan membuat kebijakan yang mendukung terciptanya industri perbankan yang sehat dan efisien sehingga peran industri perbankan sebagai sumber pembiayaan pembangunan dalam rangka meningkatkan taraf hidup rakyat banyak dapat tercapai.

\section{DAFTAR PUSTAKA}

Bain, Joe Staten, 1987. Industrial Organization, JAI Press.

Biro Riset Info Bank, Kinerja Perbankan (2009). Available online at http://www.infobanknews.com/2009

Dendawijaya, 2005. Manajemen Perbankan, Penerbit Ghalia Indonesia, Jakarta.

Ghozali, Imam, 2005. Aplikasi Analisis Multivariate dengan Program SPSS, Edisi 3, Badan Penerbit Universitas Diponegoro, Semarang.

Gujarati, Damodar.N., Porter, Dawn.C., 2010. Dasar-Dasar Ekonometrika, Edisi 5, Penerbit Salemba Empat, Jakarta.

Husnan, Suad, 1998. Manajemen Keuangan - Teori dan Penerapan, Buku 2, BPFE Yogyakarta.

Kasmir, 2005. Bank dan Lembaga Keuangan Lain, Edisi 6, PT. Raja Grafindo Perkasa, Jakarta.

Mawardi, Wisnu, 2005. Analisis Faktor - Faktor yang Mempengaruhi Kinerja Keuangan Bank Umum di Indonesia (Studi Kasus pada Bank Umum dengan Total Asset Kurang dari 1 Triliun), Jurnal Bisnis Strategi Volume 14, Nomor 1. 2005.

Peraturan Bank Indonesia Nomor 6/10/PBI/2004 Tanggal 12 April 2004. Perihal Sistem Penilaian Tingkat Kesehatan Bank Umum, Bank Indonesia, Jakarta (2004).

Peraturan Bank Indonesia Nomor 11/25/PBI/2009 Tanggal 01 Juli 2009. Perihal Perubahan Atas Peraturan Bank Indonesia Nomor 5/8/PBI/2003 tentang Penerapan Manajemen Risiko Bagi Bank Umum, Bank Indonseia, Jakarta (2004).

QE Journal | Vol.02 - No.04 - 59 
Sofyan, Sofriza, 2002. Pengaruh Struktur Pasar terhadap Kinerja Perbankan di Indonesia. Volume 2 Nomor 3 Desember 2002, Media Riset Bisnis dan Manajemen Desember 2002.

Statistik Perbankan Indonesia, Volume 10, Nomor 06, Mei 2012, Bank Indonesia, Jakarta.

Surat Edaran Bank Indonesia Nomor 6/23/DPNP Tanggal 31 Mei 2004. Perihal Sistem Penilaian Tingkat Kesehatan Bank Umum, Bank Indonesia, Jakarta.

Undang-Undang Perbankan, 1998. Undang-Undang Nomor 10 Tahun 1998

Tentang Perubahan Atas Undang-Undang Nomor 7 Tahun 1992

Tentang Perbankan, Lembaran Negara Republik Indonesia

Nomor 182. Jakarta.

QE Journal | Vol.02 - No.04 - 60 